\title{
THE USE OF VIDEO IN TEACHING WRITING ON PROCEDURE TEXT
}

\author{
Siti Aminah \\ UIN Sunan Ampel Surabaya \\ sitiaminahjamaluddin1985@gmail.com
}

\begin{abstract}
This study attempts to answer three research questions dealing with the use of video in teaching writing on procedure text. The questions are; 1) How is the use of video in teaching writing on procedure text? 2) How are the students' writing after the use of video? and 3) How are the students' responses towards the use of video in teaching writing on procedure text? since this study is descriptive qualitative study, the writer describes and analyzes the existing phenomena during the study. Furthermore, there were three kinds of instruments used in this study. They were observation checklist, students' writing, and questionnaire. Based on the findings, the writer noticed that the use of video mostly had the same teaching learning activities although it was done in three meetings. The notes were about the analysis of teacher's activity, students' activity, teaching and learning process, material, and media used. In addition, the use of video helped students to create procedure text based on its generic structures and language features. Meanwhile, the result of students' responses showed that the students were mostly interested in video viewing and agreed that video was helpful them in getting the ideas to write.
\end{abstract}

Keywords: video; writing; procedure text

\section{INTRODUCTION}

Recognizing the importance of English in this globalization era, the era in which the development of technology is growing rapidly, the Indonesian government through the National Education Ministry has determined that English must be taught since the early age. This policy is formed on the teaching English from elementary school until senior high school. Moreover, genre based curriculum is aimed to make students become literate people. It means the people who are able to read and write. As it is stated in PP No $10 \& 19$ year 2005, language learning is expected to develop four language skills with the emphasis on reading and writing.

In schools, teaching writing is not only as an essential part of the literacy, but also for showing that the teaching learning process is being done. It means that the traditional writing lesson is absolutely quite, so the teacher is able to control easily by giving them homework. Unfortunately, the fact shows that the homework can make students lazy and less progress 
because they are lack of motivation, receive bad mark, and end up in disliking writing more and more.

For those reasons, the teacher plays an important role to be a good motivator. Harmer (2001:261) states that one of the principal roles in writing tasks will be to motivate the students, create ideas, persuade them of the usefulness of the activity, and encourage them to make beneficial effort as much as possible. The beneficial effort of teaching writing may take special and long process that should be started from the very beginning since elementary school up to university students.

In junior high school, although writing in English is a compulsory subject, the fact shows that the students often get difficulties in creating both oral and written text. Thus, they are extremely lacking of motivation to learn English. To raise their motivation, the teacher should try to find some ways to develop their vocabularies and explore their ideas. In this case, technology, particularly video, can be used as one way to teach students to write. It is because video can give the real model of the target language. As Sherman (2003:3) claims that there is a special thrill in being able to understand and enjoy the real thing in video. Moreover, video provides a clear short term achievable aim for students, and by implementing video in teaching writing, the teacher can help the students to overcome one of the difficulties mentioned above.

Due to those reasons, the writer would like to do a study dealing with the use of video to teach writing on procedure text to junior high school students. The writer focuses her study on the procedure text. She chooses this text for several reasons. First, procedure text is really close to the daily activities. Therefore, procedure text should not be strange for the students or the teachers. Furthermore, the focus of teaching text is on the quality of the text, not its quantity. It does not matter how long the text is, but students are expected to construct it based on its generic structures and language features (Depdiknas, 2004:17). Second, considering the differences of the structure and culture from one language to another, students should be provided the authentic material that is appropriate for the English culture.

Therefore, the writer attempts to investigate the use of video in teaching writing on procedure text, in this case, the students' writing after the use of video and the students' responses after the use of video.

\section{REVIEW OF LITERATURE}

We realize that writing is the most difficult language skill since we have to think about how to express and organize ideas into statements and paragraphs as clear as possible. Nunan 
(2003:88) implies that writing is the mental work of inventing ideas, thinking about how to express them, and organizing them into statements and paragraphs until it is clearer to the readers.

When notes are written well, they are comprehensive and understandable. Moreover, people can communicate indirectly to another through language written down. As Byrne (1979:1) says that writing is one of the language skills that is used for medium of communication, especially, for indirect communication.

According to Bramer and Sedley (1981:4), writing will be continuing to be important part of life, especially in college course and in many careers and professions. It shows that writing is very important for the students' future, especially if they want to be a writer or journalist. Nevertheless, expressing thought through writing is not easy for most people. It means that they should read a lot to get an interesting idea.

Furthermore, Setiyadi (2006:69) states that writing in the target language can be introduced shortly after language learners have begun to read. Brown (1994:331) also claims that by reading and studying a variety of relevant types of texts, students can gain important insight both about how they should write and about the subject. It means that the students have to know what kinds of texts they should write and understand how to construct them in a good way.

At this point, constructing a good writing is not an easy thing since the writers should provide appropriate vocabulary, use correct grammar and other elements to make their writing understandable. As Zhang and Chen (1989:34) state that the writer should be able to use grammar, vocabulary, conception, rhetoric, and others elements. In this case, grammar takes an essential part in writing since language is constructed by grammar (Harmer, 2001:12). It means that we have to be able to produce sentences that are grammatically correct.

In addition, there are four reasons to teach writing. First, teaching writing is reinforcement. It means that some students acquire language in oral way, but most of them get it from seeing the language in written way. Second, teaching writing is a language development. The actual process of writing helps them to learn as they go along. Third, it is considered as a learning style. Some students are fantastically quick at picking up language just by looking and listening. Fourth, writing is a skill. It is the most important reason for teaching writing. It is a basic language skill, just as important as speaking, listening, and reading. Therefore, students need to know how to write letters, how to put written reports together, how to reply to advertisements, and how to write using electronic media (ibid). 
Video, as one of electronic media, can be an alternative way to teach writing. In this case, Safra et al. (2002:355) define video as videotape. They define it as an electromechanical device that records and reproduces an electronic signal containing audio and video information onto and from magnetic tape. It is commonly used for recording television productions that are intended for rebroadcasting to mass audiences.

Video becomes popular nowadays because educational world also uses it as one of the media in the teaching and learning process. There are some reasons why video can be used in this process. First, Chau (2003:2) points out that video can motivate and help students to use the language naturally in their own lives by seeing how the characters succeed in communicating with native speakers and getting things done in their daily activities. Second, Sherman (2003:2) states, "authentic video can be a model for specific language items or a general pool for students to pick and choose from". It means that video illustrates the kind of interactive language that most foreign language students seldom encounter. Third, video is considered as a good thing to see English culture. It shows how people live, think, and behave in the culture. In addition, video can be as a stimulus or input. It means that video can be used for discussions, for writing assignments, as input for projects or the study of other subjects.

Related to the learning activity, video can motivate and stimulate students to write. Stempleski and Tomalin (1990) imply that the use of video can provide background information and proper stimuli for subsequent reading, writing, speaking, and listening activities. In addition, it can be a good alternative, offers the flexibility and can stimulate oral and written communication among the students. Dupuy (2001:10) also claims that video can be used to motivate students to learn essential writing skill. Furthermore, the use of video can make language more accessible for students by making it easier to integrate and contextualize writing activities (Chau, 2003:2).

\section{RESEARCH METHODS}

In conducting the research, research design plays an important role in obtaining the data. It is the way information gained from the subjects. In this matter, the writer used descriptive qualitative study as the research design. This design focuses on understanding and meaning through verbal narratives and observations rather than through numbers (McMillan, 1996). Therefore, the result of the research is in the form of description and interpretation of some phenomena that exist during the research.

The subjects of the study were the students of VII-A Mts Ashfiyah Surabaya which consist of eleven boys and fourteen girls. The selected class was based on the consideration 
that the English ability of the students is on the average. Furthermore, seventh graders are expected to be able to understand and create procedure text on the basis of its generic structures and its language features. The instruments used were observation checklist, students' writing, and questionnaire.

The data was collected through non-participant observation. It was an observation in which the writer only observed the process of teaching and learning. To obtain the data related to the use of video in teaching writing procedure text, students' writing was taken to investigate their writing ability since the use of video was expected to help students to create procedure text based on its generic structure and language feature. Furthermore, the students' responses towards the use of video in teaching writing procedure text were regarded very important. Thus, the writer spread out questionnaires to investigate how far students' interest in joining the class. There were twenty five questions in the questionnaire and they were in the form of multiple choice.

\section{RESULTS AND DISCUSSION}

\subsection{The Use of Video in Teaching Writing on Procedure Text}

Based on the results of the observation about the use of video in teaching writing on procedure text, there were some points that could be elaborated further. The points were dealing with the teacher's activity, the students' activity, teaching and learning process, material used, and media used.

\section{The teacher's activity}

In the use of video in teaching writing on procedure text, the writer observed that the teacher had prepared the material before. It could be seen that there were three kinds of material dealing with procedure text. They were "How to make a cup of tea", "How to make fruit iced tea", and "How to make egg omelet". After preparing the material, the teacher introduced the topic to the students in every meeting. She always introduced the topic at the beginning of the lesson. After that, the teacher stimulated the students about the related material before starting the lesson. The stimulation always related to the daily activity. In this case, the teacher gave the example how a mother taught her child to eat something and how to do something. The teacher only gave the example at the first meeting.

Considering the students had understood the example given, the teacher then explained the nature of procedure text, its generic structures, and its language features. She explained them in a simple way. Therefore, the students could understand her explanation. After explaining more about them, the teacher always asked the students some questions related to 
the materials given. Since the teacher's explanation was regarded clear enough for them, the students were able to answer most of the teacher's questions. Furthermore, in every part of the meetings, the teacher always introduced new vocabularies to the students. For example, boil, add, put, stir, etc. Realizing that giving chances to the students to ask some question was important, the teacher always motivated them to ask any kind of question related to the material given. However, since the students were still in the seventh grade and the material was new for them, the students were mostly silent without asking anything.

The students, nevertheless, were mostly silent; the teacher considered that they must have had many difficulties in the process of their learning. Thus, the teacher asked the students' difficulties and helped to overcome them. In this matter, the teacher rarely helped the students in writing procedure text, but she always gave feedback to the students' writing. The feedback was in the form of teacher's commentary.

\section{The students' activity}

The students' activity became one of the parts in the observation about the use of video in teaching writing on procedure text. In this part, the students gave responses to the teacher's explanation about the nature of procedure text, its generic structures, and its language features. They did not only answer all of the teacher's questions but also understand her explanation. It could be seen when the teacher asked one of her students named "Ade". He could answer the question about what procedure text is. These phenomena indicated that the students actively follow the lesson. However, when it came to writing activity, the students still faced many difficulties in composing the text. The difficulties were mostly in term of vocabularies. Seeing this condition, the teacher always gave feedback to the students' writing. Fortunately, the students understood her feedback. The feedback itself was in the form of commentary.

\section{Teaching and Learning process.}

The teaching and learning process consisted of three stages. They were pre-viewing activity, viewing activity, and post-viewing. These stages indicated some techniques in the use of video in teaching learning process. The techniques were active viewing, freeze framing, repetition, and reproduction activity.

Firstly, in pre viewing activity, the teacher had prepared the media selectively. The teacher really selected the media with the consideration that it could make the students easier to understand the topic. It could be seen that the media used was in the form of short video. Since the media used was videos in native language and fitted with students' level, the teacher believed that it could make the teaching learning process not monotonous anymore. It could 
bring new, fresh atmosphere in her teaching and learning process. After selecting the media, the teacher, then, introduced the activity to the students. The introduction was in the form of asking the students' prior knowledge and related information of the topic. The topic itself was really close to the daily activity, such as how to make a cup of tea, how to make fruit iced tea, and how to make egg omelet.

Secondly, after introducing the topic, the teaching learning process came to viewing activity. In this stage, the teacher played the video several times that indicated repetition. Since the video was played several times, the students gave fully attention to it. Furthermore, in the middle of viewing, the teacher and the students made a short discussion about the visualization. The discussion was about what the narrator said, what he was doing, and what things he used.

The last stage was post-viewing. In this stage, the teacher asked the students' difficulties and new vocabularies found in the visualization. She, then, tried to overcome them. After overcoming the students' difficulties, the students were asked to write a composition based on the theme of visualization they watched on that day. In the process of writing, the teacher allowed the students to have some discussion with their friend.

\section{Material}

The material given in the writing class was in accordance with the curriculum, as it has been stated in the first chapter that seventh graders were expected to be able to understand and create procedure text based on its generic structures and language features (Depdiknas, 2004:17). Since the material given fitted with the students' interest, it could make them actively participated in the class.

\section{Media}

The media used was good. It could be seen and heard clearly to the whole class. Thus, the students really enjoyed and paid more attention to the detail of the video. During watching the video, the students concentrated with their own viewing. They took notes of what was being presented in the video. Because of their concentration, they did not take any care to others. It meant that the use of video in the teaching learning process could take much more students' attention.

\subsection{The Students' Writing after the Use of Video}

Regarding with the students' writing, the result showed that the use of video helped students to understand and develop their ideas in writing procedure text based on its generic structures and language features. In this matter, the students' writing ability in term of generic structures could be seen from the result of students' writing ability progress in term of 
organization and content, while their ability in term of language features could be seen from the result of students' writing ability progress in term of grammar, style and quality of expression.

Based on the finding of research in each term, many students could reach satisfactory result since most of students got good level in their final score (see the appendix).

\subsection{The Students' Responses after the Use of Video}

From the data of the questionnaire, the writer found out that most students liked English and the use of video as a media in English teaching learning process. They stated that the media was interesting and understandable. Although some of them said so, some others said that they did not really understand the narrator's saying. The writer noticed that it happened because the material was new for them and because of their lack of vocabulary. The fact showed that they often asked their friends or the teacher to find the meaning of the difficult word.

Considering writing is the most difficult thing to do, almost all students said that the use of video in teaching writing on procedure text helped them in getting the idea to write. It was also supported by the teacher's explanation and approach. $76 \%$ of the students said that the teacher's explanation was very clear and $64 \%$ of them said that the teacher often approached them. Therefore, they could rewrite the video viewing well.

\section{CONCLUSION}

In the use of video in teaching writing on procedure text, there are three stages of video viewing. Those are pre-viewing activity, viewing activity, and post-viewing activity. In pre viewing activity, the teacher stimulates and motivates the students in order to be well prepared with the topic. In viewing activity, the teacher plays the video several times then discusses the topic with the students. In post viewing activity, the teacher asks the students' difficulties during visualization then helps them to find the solution. After that, the teacher asks the students to rewrite the theme of visualization.

In the form ofthe students' writing from the first until the last meeting, the writer notices that the students have different styles in expressing their ideas in term of organization, content, grammar, style and quality of expression. Thus, the students presented different results and progress.

The last but not least, the students' responses towards the implementation of video in teaching writing procedure text are good. They agree that the use of video in teaching writing 
is very helpful in getting the ideas to write. Thus, the students agree that video is used as a media in teaching writing.

\section{REFERENCES}

Bramer, G. R. \& Sedley, D. (1981). Writing for Readers. Ohio: Merill Publishing Co.

Brown, H. (1994). Teaching by Principle: An interactive Approach to Language Pedagogy. New Jersey: Prentice Hall.

Byrne, D. (1979). Teaching Writing Skill. Hongkong: Longman Group. Ltd.

Chau, E. (2003). Developing Beginner Language Skill through Video. AMEP Conference.

Depdiknas. (2004). Kurikulum 2004: Standar Kompetensi Mata Pelajaran Bahasa Inggris SMP/Mts. Jakarta: Depdiknas.

Dupuy. (2001). Teaching Argumentative Through Film.TESOL Journal, 10(4), 30-33.

Harmer. (2001). The Practice of English Language Teaching. London : Pearson Education Limited.

McMillan. (1996). Educational Research: Fundamentals for the Consumer (2nd Ed.)New York: HarperCollins Publishers.

Nunan, D. (2003). Practical English Language Teaching. New York : McGraw-Hill.

Safra J, et. al. (2002). The New Encyclopedia Britannica. New York: Encyclopedia Britannica,Inc.

Sherman. (2003). Using Authentic Video in the Language Classroom. Cambridge: Cambrigde University Press.

Setiyadi, B. (2006). Teaching English as a foreign language. Yogyakarta: Graha Ilmu.

Stempleski, S. \& Barry, T. (1990). Video In Action: Recipes for Using Video in Language Teaching. London: Prentice Hall, Inc.

Zang, X. \&Chen Shin Jin. (1989). Techniques to teach Writing. English Teaching Forum,27, http://www.youtube.com/watch?v=EDqW7QsUjme. Retrieved on March 8, 2009.

http://www.youtube.com/watch?v=5QeudDBu5Y. Retrieved on March 8, 2009.

http://www.youtube.com/watch?v=Ae44gDxx-h0. Retrieved on March 8, 2009. 


\section{Appendix}

Students' Score in Writing

Notes :

\begin{tabular}{|c|c|c|c|c|c|c|c|}
\hline \multirow[t]{2}{*}{ No } & \multicolumn{2}{|c|}{ First meeeting } & \multicolumn{2}{|c|}{ Second Meeting } & \multicolumn{2}{|c|}{ Third Meeting } & \multirow[t]{2}{*}{ Progress } \\
\hline & Score & Criteria & Score & Criteria & Score & Criteria & \\
\hline 1 & 68 & G & 65 & G & 56 & $\mathrm{~F}$ & -1 \\
\hline 2 & 59 & $\mathrm{~F}$ & 50 & $\mathrm{P}$ & 73 & G & +1 \\
\hline 3 & 59 & $\mathrm{~F}$ & 59 & $\mathrm{~F}$ & 77 & G & +1 \\
\hline 4 & 59 & $\mathrm{~F}$ & 59 & $\mathrm{~F}$ & 75 & G & +1 \\
\hline 5 & 62 & $\mathrm{~F}$ & 62 & $\mathrm{~F}$ & 67 & G & +1 \\
\hline 6 & 74 & G & 74 & G & 77 & G & 0 \\
\hline 7 & 68 & G & 68 & G & 72 & G & 0 \\
\hline 8 & 68 & G & 68 & G & 71 & G & 0 \\
\hline 9 & 47 & $P$ & 47 & $\mathrm{P}$ & 66 & G & +2 \\
\hline 10 & 68 & G & 56 & $\mathrm{~F}$ & 71 & G & 0 \\
\hline 11 & 68 & G & 71 & G & 72 & G & 0 \\
\hline 12 & 63 & $\mathrm{~F}$ & 73 & G & 74 & G & +1 \\
\hline 13 & 63 & $\mathrm{~F}$ & 71 & G & 72 & G & +1 \\
\hline 14 & 56 & $\mathrm{~F}$ & 62 & $\mathrm{~F}$ & 69 & G & +1 \\
\hline 15 & 68 & G & 62 & $\mathrm{~F}$ & 72 & G & 0 \\
\hline 16 & 68 & G & 50 & $\mathrm{P}$ & 66 & G & 0 \\
\hline 17 & 19 & UA & 44 & $\mathrm{P}$ & 69 & G & +3 \\
\hline 18 & 68 & G & 62 & $\mathrm{~F}$ & 51 & $\mathrm{~F}$ & -1 \\
\hline 19 & 68 & $\mathrm{G}$ & 50 & $\mathrm{P}$ & 76 & G & 0 \\
\hline 20 & 62 & $\mathrm{~F}$ & 56 & $\mathrm{~F}$ & 69 & G & +1 \\
\hline 21 & 68 & G & 73 & G & 58 & $\mathrm{~F}$ & -1 \\
\hline 22 & 63 & $\mathrm{~F}$ & 53 & $\mathrm{~F}$ & 71 & G & +1 \\
\hline 23 & 63 & $\mathrm{~F}$ & 16 & UA & 69 & G & +1 \\
\hline 24 & 62 & $\mathrm{~F}$ & 73 & G & 67 & G & +1 \\
\hline 25 & 59 & $\mathrm{~F}$ & 71 & G & 69 & $\mathrm{G}$ & +1 \\
\hline UA & :Unacep & ble & & & & & \\
\hline $\mathrm{P}$ & : Poor & & & & & & \\
\hline $\mathrm{F}$ & : Fair & $: 5$ & & & & & \\
\hline G & : Good & $: 6$ & & & & & \\
\hline $\mathrm{E}$ & : Excelle & $: 8$ & & & & & \\
\hline
\end{tabular}

